\title{
Herbage accumulation and grazing losses on Mulato grass subjected to strategies of rotational stocking management
}

\author{
Márcia Cristina Teixeira da Silveira1 ${ }^{1}$, Sila Carneiro Da Silva ${ }^{*}$, Salim Jacaúna de Souza Júnior ${ }^{3}$, Leandro Martins Barbero ${ }^{4}$, Carlindo \\ Santos Rodrigues ${ }^{5}$, Veridiana Aparecida Limão2, ${ }^{2,}$ Karine da Silva Pena ${ }^{6}$, Domicio do Nascimento Júnior ${ }^{6}$
}

'Embrapa Pecuária Sul/CPPSUL, Rod. BR 153, km 603 - Vila Industrial - $96401-970$ - Bagé, RS - Brasil. 2USP/ESALQ - Depto. de Zootecnia, Av. Pádua Dias, 11 13418-900 - Piracicaba, SP - Brasil.

IFAM - Depto. de Agronomia, Estrada Odovaldo Novo, s/n69151-000 - Parintins, AM - Brasil.

${ }^{4}$ UFU - Depto. de Zootecnia, Av. Pará, 1720 bloco 2T 38400-902 - Uberlândia, MG - Brasil.

5FFBA - Depto. de Zootecnia, Av. João do Nascimento, s/n - 45680-000 - Campus Uruçuca, Ba - Brasil.

${ }^{6}$ UFV - Depto. de Zootecnia, Av. P.H. Rolfs, s/n - Campus

Universitário - 36570-000 - Viçosa, MG - Brasil.

*Corresponding author <siladasilva@usp.br>

Edited by: Daniel Scherer de Moura

Received December 17, 2012

Accepted February 15, 2013

\begin{abstract}
Grazing management strategies affect not only herbage accumulation but also the efficiency of grazing. This study aimed to evaluate herbage accumulation (leaf, stem and dead material), grazing efficiency and losses of mulato grass (a Brachiaria ruziziensis $\times$ Brachiaria brizantha cv. Marandu hybrid) subjected to strategies of rotational stocking management. Treatments consisted of combinations between two post-grazing heights (15 and $20 \mathrm{~cm}$ ) and two pre-grazing conditions (95\% and maximum canopy light interception (LI)) assigned to experimental units (1200- $\mathrm{m}^{2}$ paddocks) according to a $2 \times 2$ factorial arrangement and a randomized complete block design, with four replications. The experiment was carried out from Jan 2008 to Mar 2009. Season of the year influenced almost all studied variables, resulting in a common pattern of response that was determined by pre- and post-grazing management targets. Herbage accumulation was greater on swards managed at $95 \%$, with higher accumulation of leaves and lower accumulation of stem and dead material in relation to those managed at maximum LI (99 \%) during the entire experimental period. On the other hand, herbage removal by grazing was larger on swards managed at $99 \% \mathrm{LI}$, which was compensated for by the smaller number of grazing cycles and larger losses due to grazing under those circumstances. Under rotational stocking, the pre-grazing LI of $95 \%$ and post-grazing height of $20 \mathrm{~cm}$ resulted in efficient grazing and high producing leafy pastures, highlighting the potential of Mulato grass pastures for animal production.

Keywords: Brachiaria spp., grazing efficiency, light interception, grazing management
\end{abstract}

\section{Introduction}

On grasslands, animal productivity is a function of herbage accumulation, quality and efficiency of harvest by the grazing animals. In that context, a number of studies have been conducted with the main goal of evaluating new genetic materials with higher dry matter yield potential and with other desirable qualitative traits, including adaptation to a wide range of climatic, edaphic and biotic conditions. Mulato grass, a Brachiaria ruziziensis $\times$ Brachiaria brizantha cv. Marandu hybrid, is an example of cultivar with such traits. In order to exploit the productive potential of pasture plants, it is essential that they be grown in favorable environments and managed to ensure harvest of herbage at the optimal time. However, grazing management strategies can interfere with the herbage accumulation process, harvest efficiency and herbage utilization (Pedreira et al., 2005). Thus, raising animals on pastures involves dealing with the interaction of biotic and abiotic factors and, therefore, requires knowledge of the plant-animal-environment interface for designing and implementing appropriate and effective management strategies (Da Silva and Carvalho, 2005).

\$Present address: IFTM - Depto. de Zootecnia - Campus Uberaba - Unidade I, Rua João Batista Ribeiro, 4000 - Unid I Mercês, $38064-790$ - Uberaba, $M G$ - Brasil.
Among a range of grazing methods, intermittent stocking methods is one of the most commonly used. Inherent to the optimal implementation of this stocking method is the basic assumption that the correct time is known for interrupting the regrowth process to maximize leaf dry matter accumulation and achieve high levels of grazing efficiency. Recent studies conducted with tropical forage grasses (Difante et al., 2009; Silveira et al., 2010; Cunha et al., 2010) have indicated that $95 \%$ light interception (LI) corresponds to the appropriate time for interrupting the regrowth process of species because it maximized leaf dry matter accumulation and ensures high grazing efficiency (Carnevalli et al., 2006). To ensure high levels of intake and performance, grazing should be interrupted when sward height reaches 40 to $60 \%$ of the pre-grazing height (Fonseca et al., 2012). However, information regarding grazing management of mulato grass is scarce. Therefore, the objective of this study was to evaluate herbage accumulation and morphological composition, as well as grazing losses and the efficiency of the grazing process of mulato grass subjected to strategies of rotational stocking management.

\section{Materials and Methods}

The experiment was carried out at Piracicaba, state of São Paulo, Brazil, $\left(22^{\circ} 42^{\prime} \mathrm{S}, 47^{\circ} 37^{\prime} \mathrm{W}\right.$ and $550 \mathrm{~m}$ a.s.1), on a moderately rolling transition between a Mol- 
lisol and a Vertisol (USDA Soil Taxonomy) of high fertility (chemical composition of the $0-20 \mathrm{~cm}$ layer were (van Raij et al., 1986): $0.01 \mathrm{M} \mathrm{CaCl}_{2} ; \mathrm{pH}=5.5$; organic matter $=38.5 \mathrm{~g} \mathrm{dm}^{-3} ; \mathrm{P}$ (ion-exchange resin) $=82 \mathrm{mg} \mathrm{dm}^{-3}$; $\mathrm{Ca}=104 \mathrm{mmol}_{\mathrm{c}} \mathrm{dm}^{-3} ; \mathrm{Mg}=30 \mathrm{mmol}_{\mathrm{c}} \mathrm{dm}^{-3}, \mathrm{~K}=6.4$ $\mathrm{mmol}_{\mathrm{c}} \mathrm{dm}^{-3} ; \mathrm{H}+\mathrm{Al}=30 \mathrm{mmol}_{\mathrm{c}} \mathrm{dm}^{-3}$; sum of bases $=$ $140 \mathrm{mmol}_{\mathrm{c}} \mathrm{dm}^{-3}$; cation exchange capacity $=171 \mathrm{mmol}_{\mathrm{c}}$ $\mathrm{dm}^{-3}$; and base saturation $\left.=82 \%\right)$. According to Köppen classification, the climate is Cwa type (i.e., mesothermal humid subtropical with a dry winter). Information regarding the climatic conditions during the experimental period was obtained from a meteorological station located approximately $500 \mathrm{~m}$ from the experimental site. Monthly average maximum, mean and minimum temperatures and precipitation measured during the experimental period are shown in Figure 1, and data were used to calculate monthly soil water balance (Thornthwaite and Mather, 1955) using $50 \mathrm{~mm}$ as available water capacity (AWC) (Figure 2).

Pastures were established in Nov 2004 using 5 $\mathrm{kg} \mathrm{ha} \mathrm{h}^{-1}$ of pure and viable Brachiaria cv. Mulato (CIAT 36061) hybrid seeds and were maintained under rota-

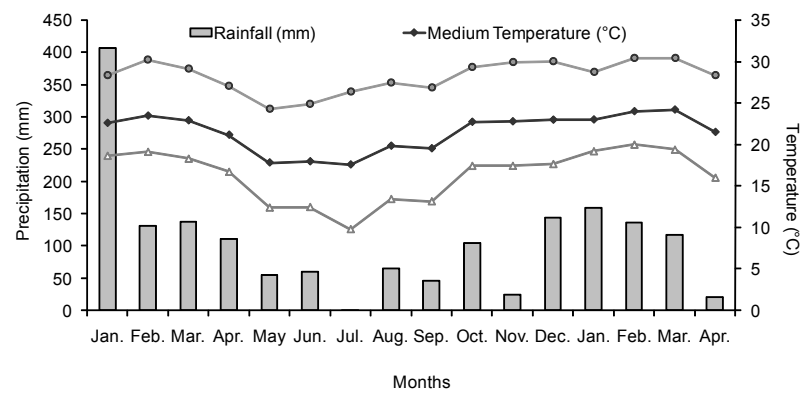

Figure 1 - Monthly averages of mean, maximum and minimum air temperature and precipitation in the experimental area from Jan, 2008 to Apr, 2009.

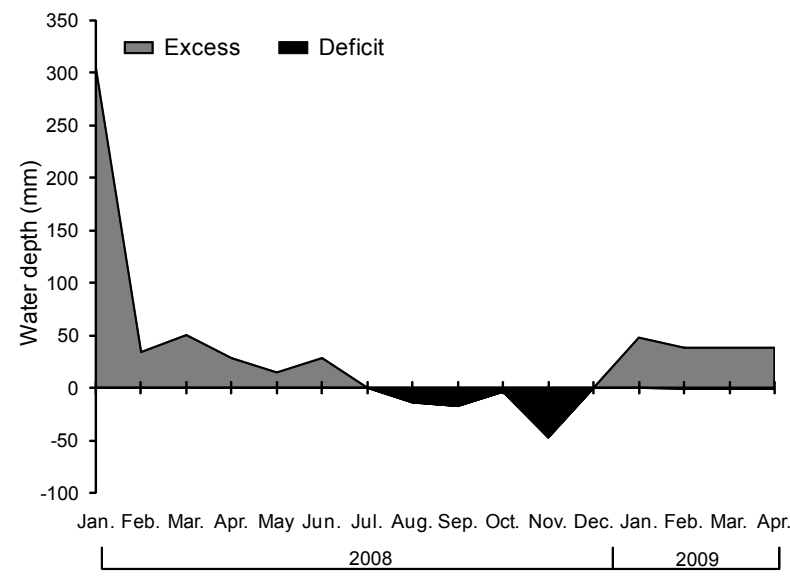

Figure 2 - Monthly soil water balance for the experimental area from Jan, 2008 to Apr, 2009. tional stocking until Nov 2007, when the area was staged to approximately $10 \mathrm{~cm}$ by grazing and using a mower to ensure uniformity. After mowing, $60 \mathrm{~kg} \mathrm{ha}^{-1} \mathrm{~N}$ (ammonium nitrate) were applied, and monitoring of regrowth on each of the sixteen experimental units $\left(1200-\mathrm{m}^{2}\right.$ paddocks) for canopy light interception (LI) and height was initiated. In total, $270 \mathrm{~kg} \mathrm{ha}^{-1}$ year $^{-1}$ of $\mathrm{N}$ were applied during the warm and rainy season (late spring and summer), including the initial fertilization. The experiment began in Jan 2008, after a complete round of grazing on all experimental pastures that provided opportunity to establish the targets of post-grazing height.

Treatments consisted of combinations between two post-grazing heights $(15$ and $20 \mathrm{~cm})$ and two pregrazing conditions $(95 \%$ and maximum canopy light interception - LI). The four treatments were assigned to experimental units according to a $2 \times 2$ factorial arrangement and a randomized complete block design, with four replications. Grazing was carried out by Nelore and Canchim heifers with an initial average body weight of $250 \mathrm{~kg}$ using the mob-grazing technique (Gildersleeve et al., 1987). Animal numbers were varied as needed to accomplish the grazing in 12 hours (daytime grazing only).

Monitoring of canopy LI was conducted at postgrazing, soon after the animals were removed from the pasture; weekly during regrowth until $90 \% \mathrm{LI}$; and, from that point onward, every two days until the pregrazing targets of 95 and maximum LI was conducted using a canopy analyzer LAI 2000 (LI-COR Biosciences, 1992). Measurements were obtained in ten sampling areas per paddock (on sites representative of the average sward condition at the time of sampling - visual assessment of sward height and herbage mass). In each sampling area, five measurements were taken at ground level and one measurement was taken above the canopy, totaling 50 measurements at ground level and ten measurements above the canopy per experimental unit. The maximum LI condition (99 \%) was determined during the first two regrowth after mowing, and was considered to occur when LI was stable during two consecutive measurement dates. Sward pre- and post-grazing heights were evaluated concomitantly to LI monitoring using a sward stick (Barthram, 1985). A total of 100 readings per paddock were taken along predefined zigzag trajectories that were used throughout the experimental period.

Measurements of herbage mass pre- and postgrazing were carried out on areas representative of the average sward condition at the time of sampling (visual assessment of the sward height and herbage mass) using three $0.90 \times 0.37 \mathrm{~m}\left(0.33 \mathrm{~m}^{2}\right)$ metallic frames per paddock. Herbage within the frames was cut to ground level using an electric hedge trimmer, sub-sampled, and hand separated into leaves (leaf lamina), stems (leaf sheaths and stems) and dead material. After separation, morphological components were put to dry separately in a forced-draught oven at $65{ }^{\circ} \mathrm{C}$ until constant weight. 
Herbage mass and morphological composition were calculated accordingly. Herbage accumulation was determined as the difference between pre-grazing and previous post-grazing herbage mass.

Litter losses to the soil pathway (grazing losses) were quantified using two $1.0 \times 2.0 \mathrm{~m}\left(2.0 \mathrm{~m}^{2}\right)$ frames in each experimental unit. At the time of pre-grazing measurements, frames were allocated in areas representative of average sward condition (visual assessment of height and herbage mass) and all surface litter (green material un-rooted and dead plant material on the ground) removed, leaving a clean soil surface. After grazing, these areas were re-visited and all material lying on the ground as well as broken stems and green leaves were collected. This was considered as herbage lost to litter. Samples were sub-sampled and dried in a forced-draught oven at $65^{\circ} \mathrm{C}$ until constant weight.

Herbage disappearance during grazing was calculated as the difference between pre- and post-grazing herbage mass at every grazing, and the total for the experiment as the sum of the corresponding values for every grazing cycle. Harvested herbage was calculated as the difference between total herbage disappearance during grazing and that lost to litter. Litter losses were then expressed as a proportion $(\%)$ of total herbage disappearance, and its complement to 100 was considered as grazing efficiency.

As a result of the way treatments were defined, grazing dates and rest periods for each experimental unit were variable, so data were grouped according to seasons of the year for uniformity (summer 2008 (Jan 1 to Mar 31, 2008); autumn/winter/early spring (Apr 1 to Nov 15, 2008); late spring (Nov 16 to Dec 31, 2008); and summer 2009 (Jan 1 to Mar 31, 2009)), and values for individual paddocks were weighted for the duration of records within seasons.

Analysis of variance was carried out on the grouped data using the Mixed Procedure of SAS ${ }^{\circledR}$ (Statistical Analysis System). The choice of the covariance matrix was made using the Akaike Information Criterion (AIC) (Wolfinger, 1993), and analysis performed considering light interception pre-grazing, post-grazing height, season of the year and their interactions as fixed effects and blocks as a random effect. When appropriate, treatment means were calculated using the
"LSMEANS" statement, and comparisons made using Student T test $(p<0.05)$. Data on total dry matter accumulation, herbage disappearance and losses due to grazing for the experiment were analyzed using the GLM Procedure of SAS.

\section{Results}

Pre-grazing height of swards managed at 95 and 99 $\%$ LI remained relatively stable throughout the experiment and corresponded to 30 and $40 \mathrm{~cm}$, respectively. The post-grazing height targets of 15 and $20 \mathrm{~cm}$ were relatively easy to establish and maintain only on swards managed at $95 \%$ LI. On those managed at $99 \%$ LI it was not possible to maintain the $15 \mathrm{~cm}$ target (Table 1). In general, larger values of herbage mass pre- and postgrazing were recorded on swards managed at $99 \%$ relative to those managed at $95 \% \mathrm{LI}$, especially for $20 \mathrm{~cm}$ post-grazing height. On the other hand, on swards managed at $95 \%$ LI, with shorter grazing intervals, the total number of grazing cycles at the end of the experiment was larger.

Rates of herbage accumulation varied with postgrazing height $(p=0.0212)$, season of the year $(p<$ $0.0001)$ and season of the year $\times$ LI $(p=0.0030)$ and season of the year $\times$ post-grazing height $(p=0.0055)$ interactions. In general, higher accumulation rates were recorded during summer (2008 and 2009). Except for autumn/winter/early spring, when there was no differences between LI and post-grazing height treatments (Tables 2 and 3, respectively), higher values were recorded on swards managed at $95 \%$ relative to those managed at $99 \%$ LI during summer 2008 and 2009 (Table 2) and on swards managed with the $20 \mathrm{~cm}$ relative to those managed with the $15 \mathrm{~cm}$ post-grazing height (Table 3).

The rate of leaf accumulation was influenced by season of the year ( $p=0.0016)$ and season of the year $\times$ LI interaction $(p=0.0284)$. Higher values of leaf accumulation rate were recorded during summer 2008 and 2009 on swards managed at $95 \%$ relative to those managed at $99 \%$ LI, whereas no differences were recorded during autumn/winter/early spring and late spring (Table 4). Swards managed at $95 \%$ LI showed a reduction in leaf accumulation rate only during the less favorable periods for plant growth, but, in contrast, on swards man-

Table 1 - Average sward height and herbage mass pre- and post-grazing, total number of grazing cycles and range of variation (minimum and maximum values) for grazing intervals of Mulato grass subjected to strategies of rotational stocking management from Jan, 2008 to Mar, 2009.

\begin{tabular}{|c|c|c|c|c|c|c|c|}
\hline Treatments & $\begin{array}{c}\text { Pre-grazing } \\
\text { height }\end{array}$ & $\begin{array}{c}\text { Post-grazing } \\
\text { height }\end{array}$ & $\begin{array}{c}\text { Pre-grazing } \\
\text { herbage mass }\end{array}$ & $\begin{array}{c}\text { Post-grazing } \\
\text { herbage mass }\end{array}$ & $\begin{array}{l}\text { Number } \\
\text { of grazing } \\
\text { cycles }\end{array}$ & $\begin{array}{l}\text { Grazing interval } \\
\text { (minimum) }\end{array}$ & $\begin{array}{l}\text { Grazing interval } \\
\text { (maximum) }\end{array}$ \\
\hline & \multicolumn{2}{|c|}{$-\mathrm{cm}-$} & \multicolumn{2}{|c|}{$\longrightarrow \mathrm{kg} \mathrm{ha}^{-1} \longrightarrow$} & & \multicolumn{2}{|c|}{$\longrightarrow d-$} \\
\hline $95 / 15$ & 28.9 & 14.9 & 6290 & 4100 & 11 & 11 & 209 \\
\hline $95 / 20$ & 29.7 & 20.0 & 6700 & 4720 & 13 & 7 & 189 \\
\hline $99 / 15$ & 41.0 & 19.6 & 8130 & 5460 & 7 & 28 & 234 \\
\hline $99 / 20$ & 41.4 & 20.5 & 8620 & 5830 & 8 & 21 & 225 \\
\hline
\end{tabular}


Table 2 - Rates of herbage accumulation of mulato grass subjected to strategies of rotational stocking management characterized by the pre-grazing conditions of 95 and $99 \%$ LI from Jan, 2008 to Mar, 2009.

\begin{tabular}{|c|c|c|}
\hline \multirow{2}{*}{ Season of the year } & \multicolumn{2}{|c|}{ Canopy light interception } \\
\hline & $95 \%$ & $99 \%$ \\
\hline & \multicolumn{2}{|c|}{$\mathrm{kg} \mathrm{ha}^{-1} \mathrm{~d}^{-1} \longrightarrow$} \\
\hline \multirow[t]{2}{*}{ Summer 2008} & $84.9 \mathrm{Ab}$ & $62.8 \mathrm{Ba}$ \\
\hline & $(10.4)$ & (10.4) \\
\hline \multirow[t]{2}{*}{ Autumn/winter/early spring } & $41.5 \mathrm{Ac}$ & $36.5 \mathrm{Ab}$ \\
\hline & (4.3) & (4.3) \\
\hline \multirow[t]{2}{*}{ Late spring } & $43.5 \mathrm{Ac}$ & $27.5 \mathrm{Bc}$ \\
\hline & $(4.3)$ & (4.3) \\
\hline \multirow[t]{2}{*}{ Summer 2009} & $92.4 \mathrm{Aa}$ & $62.3 \mathrm{Ba}$ \\
\hline & $(6.0)$ & $(6.0)$ \\
\hline
\end{tabular}

Summer 2008 = Jan 1 to Mar 31, 2008; autumn/winter/early spring = Apr 1 to Nov 15, 2008; late spring = Nov 16 to Dec 31,2008; and summer $2009=$ Jan 1 to Mar 31, 2009. Means followed by the same uppercase letter in rows and lowercase letter in columns are not different (Student T test; $p>0.05$ ). The values in parentheses correspond to the standard error of the mean.

Table 3 - Rates of herbage accumulation of mulato grass subjected to strategies of rotational stocking management characterized by the post-grazing heights of 15 and $20 \mathrm{~cm}$ from Jan, 2008 to Mar, 2009.

\begin{tabular}{lcc}
\hline \multirow{2}{*}{ Season of the year } & \multicolumn{2}{c}{ Post-grazing height $(\mathrm{cm})$} \\
\cline { 2 - 3 } & \multicolumn{1}{c}{15} & 20 \\
\hline \multirow{2}{*}{ Summer 2008 } & $65.5 \mathrm{Ba} \mathrm{ha}^{-1} \mathrm{~d}^{-1}-$ & $81.0 \mathrm{Aa}$ \\
& $(10.3)$ & $(10.3)$ \\
Autumn/winter/early spring & $27.0 \mathrm{Ab}$ & $24.0 \mathrm{Ab}$ \\
& $(1.6)$ & $(1.6)$ \\
Late spring & $17.5 \mathrm{Bb}$ & $32.0 \mathrm{Ab}$ \\
& $(5.9)$ & $(5.9)$ \\
Summer 2009 & $65.0 \mathrm{Ba}$ & $89.5 \mathrm{Aa}$ \\
& $(6.0)$ & $(6.0)$ \\
\hline
\end{tabular}

Summer 2008 = Jan 1 to Mar 31, 2008; autumn/winter/early spring = Apr 1 to Nov 15, 2008; late spring = Nov 16 to Dec 31, 2008; and summer $2009=$ Jan 1 to Mar 31, 2009. Means followed by the same uppercase letter in rows and lowercase letter in columns are not different (Student T test: $p>0.05$ ). The values in parentheses correspond to the standard error of the mean.

aged at $99 \% \mathrm{LI}$, the reduction occurred during autumn/ winter/early spring and was more pronounced in summer 2009.

Rates of stem accumulation varied with LI $(p=$ $0.0038)$, season of the year $(p=0.0038)$ and season of the year $\times$ LI $(p=0.0369)$, season of the year $\times$ postgrazing height $(p=0.0253)$ and season of the year $\times$ LI $\times$ post-grazing height $(p=0.0056)$ interactions. In general, greater stem accumulation rate was recorded on swards managed at $99 \%$ than on those managed at 95 $\%$ LI throughout the experimental period. There was no effect of post-grazing height on swards managed at 95 $\%$ LI. However, rates of stem accumulation were higher for the $20 \mathrm{~cm}$ than the $15 \mathrm{~cm}$ post-grazing height on
Table 4 - Rates of leaf accumulation of mulato grass subjected to strategies of rotational stocking management characterized by the pre-grazing conditions of 95 and $99 \%$ LI from Jan, 2008 to Mar, 2009.

\begin{tabular}{|c|c|c|}
\hline \multirow{2}{*}{ Season of the year } & \multicolumn{2}{|c|}{ Canopy light interception } \\
\hline & $95 \%$ & $99 \%$ \\
\hline & \multicolumn{2}{|c|}{$-\mathrm{kg} \mathrm{ha}^{-1} \mathrm{~d}^{-1}-$} \\
\hline Summer 2008 & $\begin{array}{c}43.0 \mathrm{Aa} \\
(4.3)\end{array}$ & $\begin{array}{l}38.0 \mathrm{Ba} \\
(4.3)\end{array}$ \\
\hline Autumn/winter/early spring & $\begin{array}{c}24.6 \mathrm{Ac} \\
(1.6)\end{array}$ & $\begin{array}{l}26.5 \mathrm{Ab} \\
(1.6)\end{array}$ \\
\hline Late spring & $\begin{array}{c}19.5 \mathrm{Ac} \\
(5.9)\end{array}$ & $\begin{array}{l}21.1 \mathrm{Ac} \\
(5.9)\end{array}$ \\
\hline Summer 2009 & $\begin{array}{c}33.0 \mathrm{Ab} \\
(4.3)\end{array}$ & $\begin{array}{l}19.0 \mathrm{BC} \\
(4.3)\end{array}$ \\
\hline
\end{tabular}

Summer 2008 = Jan 1 to Mar 31, 2008; autumn/winter/early spring = Apr 1 to Nov 15, 2008; late spring = Nov 16 to Dec 31, 2008; and summer $2009=$ Jan 1 to Mar 31, 2009. Means followed by the same uppercase letter in rows and lowercase letter in columns are not different (Student T test; $p>0.05$ ). Values in parentheses correspond to standard error of the mean.

Table 5 - Rates of stem accumulation of mulato grass subjected to strategies of rotational stocking management from Jan, 2008 to Mar, 2009.

\begin{tabular}{|c|c|c|}
\hline \multirow{2}{*}{ Post-grazing height (cm) } & \multicolumn{2}{|c|}{ Canopy light interception } \\
\hline & $95 \%$ & $99 \%$ \\
\hline & \multicolumn{2}{|c|}{$\mathrm{kg} \mathrm{ha}^{-1} \mathrm{~d}^{-1} \longrightarrow$} \\
\hline & \multicolumn{2}{|c|}{ Summer $2008(E P M=3.3)$} \\
\hline 15 & $4.0 \mathrm{Ba}$ & $16.0 \mathrm{Aa}$ \\
\hline \multirow[t]{2}{*}{20} & $2.5 \mathrm{Ba}$ & $11.5 \mathrm{Aa}$ \\
\hline & \multicolumn{2}{|c|}{ Autumn/winter/early spring (EPM $=1.7$} \\
\hline 15 & $1.5 \mathrm{Ba}$ & $15.5 \mathrm{Aa}$ \\
\hline \multirow[t]{2}{*}{20} & $3.5 \mathrm{Ba}$ & $9.0 \mathrm{Ab}$ \\
\hline & \multicolumn{2}{|c|}{ Late spring $(E P M=1.9)$} \\
\hline 15 & $6.0 \mathrm{Ba}$ & $17.0 \mathrm{Aa}$ \\
\hline \multirow[t]{2}{*}{20} & $5.0 \mathrm{Ba}$ & $6.0 \mathrm{Ab}$ \\
\hline & \multicolumn{2}{|c|}{ Summer 2009 (EPM = 1.4) } \\
\hline 15 & $3.0 \mathrm{Ba}$ & $14.0 \mathrm{Aa}$ \\
\hline 20 & $2.0 \mathrm{Ba}$ & $8.0 \mathrm{Ab}$ \\
\hline
\end{tabular}

swards managed at $99 \%$ LI from autumn/winter/early spring until the end of the experiment, in summer 2009 (Table 5). The rate of dead material accumulation was influenced by LI ( $p=0.0183$ ) only, with lower values recorded on swards managed at $95 \%$ relative to those managed at $99 \%$ LI 19.0 and $13.0 \mathrm{~kg} \mathrm{ha}^{-1} \mathrm{~d}^{-1} \pm 0.93$, respectively).

Herbage disappearance varied with LI $\mid p=$ $0.0058)$ and season of the year $(p=0.0050)$, with larger values recorded on swards managed at $99 \%$ relative to those managed at $95 \%$ LI (Figure 3A). Overall, largest values of herbage removal were recorded during late 

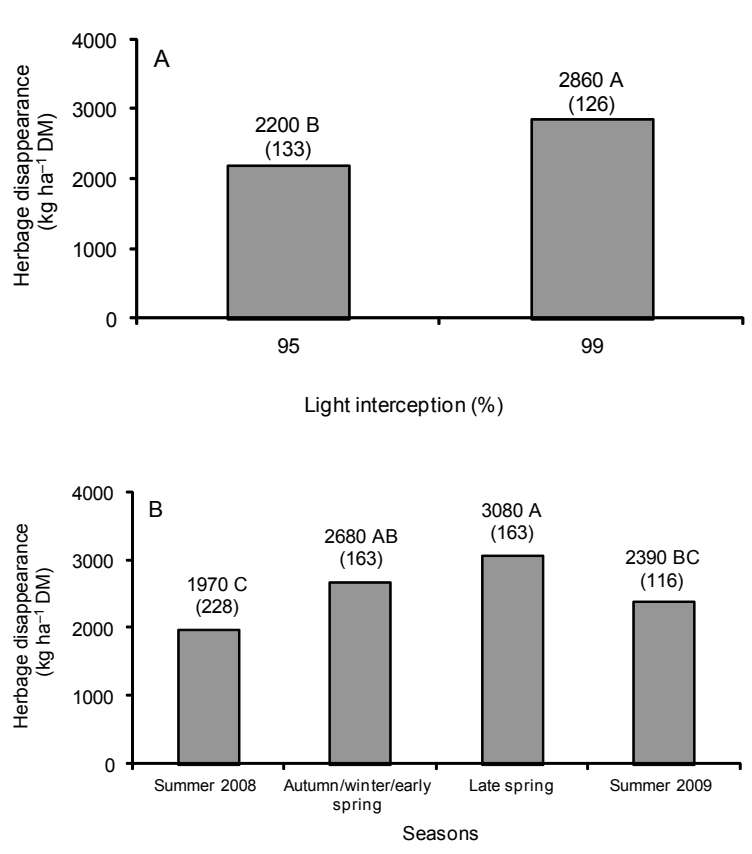

Summer 2008 = Jan 1 to Mar 31, 2008; autumn/winter/early spring = Apr 1 to Nov 15, 2008; late spring = Nov 16 to Dec 31, 2008; and summer 2009 = Jan 1 to Mar 31, 2009. Means followed by the same uppercase letter are not different $(p>0.05)$. The values in parentheses correspond to the standard error of the mean.

Figure 3 - Herbage disappearance during grazing in mulato grass subjected to strategies of rotational stocking management characterized by the pre-grazing conditions of 95 and $99 \% \mathrm{LI}$ from Jan, 2008 to Mar, 2009.

spring, lowest during summer 2008 and 2009, and intermediate values during autumn/winter/early spring (Figure 3B).

Grazing losses were influenced by LI ( $p<0$.0001), post-grazing height $(p=0.0188)$, season of the year $(p$ $<0.0001)$ and season of the year $\times$ LI interaction $(p=$ $0.0013)$. In general, herbage losses were larger on swards managed at $99 \%$ relative to those managed at $95 \%$ LI (Table 6). The difference became more pronounced as the experiment progressed (summer 2008 to late spring) and decreased only at the end of the experiment, in summer 2009. Larger values of losses due to grazing were recorded on swards managed with the $15 \mathrm{~cm}$ than the $20 \mathrm{~cm}$ post-grazing height $\left(1120\right.$ and $980 \mathrm{~kg} \mathrm{ha}^{-1} \pm 38.3$, respectively).

Grazing efficiency varied with LI $(p<0.0001)$ and season of the year ( $p=0.0007)$, with larger values recorded on swards managed at $95 \%$ relative to those managed at $99 \%$ LI (Figure 4A). Overall, grazing efficiency was largest during summer (2008 and 2009), lowest during autumn/winter/early spring, with intermediate values recorded during late spring (Figure 4B).
Table 6 - Grazing losses in mulato grass subjected to strategies of rotational stocking management characterized by the pre-grazing conditions of 95 and 99 \% LI from Jan, 2008 to Mar, 2009.

\begin{tabular}{lcc}
\hline \multirow{2}{*}{ Season of the year } & \multicolumn{2}{c}{ Canopy light interception } \\
\cline { 2 - 3 } & $95 \%$ & $99 \%$ \\
\hline \multirow{2}{*}{ Summer 2008} & $530 \mathrm{Bc}$ & $790 \mathrm{Ac}$ \\
& $(32.4)$ & $(29.9)$ \\
Autumn/winter/early spring & $1100 \mathrm{Ba}$ & $1700 \mathrm{Aa}$ \\
& $(159.6)$ & $(216.9)$ \\
Late spring & $890 \mathrm{Bab}$ & $1640 \mathrm{Aa}$ \\
& $(112.4)$ & $(126.2)$ \\
Summer 2009 & $660 \mathrm{Bb}$ & $1100 \mathrm{Ab}$ \\
& $(52.9)$ & $(53.6)$ \\
\hline
\end{tabular}

Summer 2008 = Jan 1 to Mar 31, 2008; autumn/winter/early spring = Apr 1 to Nov 15, 2008; late spring = Nov 16 to Dec 31, 2008; and summer 2009 = Jan 1 to Mar 31, 2009. Means followed by the same uppercase letter in rows and lowercase letter in the columns are not different (Student T test; $p$ $>0.05$ ). The values in parentheses correspond to the standard error of the mean. *Analysis performed on transformed data (square root).

\section{Discussion}

In pastures, only a fraction of the accumulated herbage is removed by grazing. From that, only part is effectively consumed by the grazing animals; the remaining being 'lost', characterizing inefficiency of the grazing process. High efficiency in the grazing process is not only restricted to ensuring herbage production and high proportion of leaves Carnevalli et al., 2006). It is also necessary to take into account the efficiency of harvest, which can be determined by quantifying the losses due to grazing.

In general, there was a uniform pattern of response strongly related and influenced by season of the year, consistent with the seasonality of herbage production (related with the growing environment including day length, rainfall, temperature, etc., in this environment) that is typical of tropical forage grasses (Da Silva and Carvalho, 2005). The experimental treatments, which corresponded to contrasting rotational stocking methods, influenced the magnitude of variation in response, indicating that control variables such as pre-grazing LI and post-grazing height can and should be used in research and by producers to promote adjustments in herbage accumulation process and in grazing efficiency. The fact highlights the importance and the potential use of management targets as a means of intensifying livestock production from pastures through increased herbage production and efficiency of harvest (Da Silva et al., 2009).

The highest rates of herbage accumulation recorded during summer (Table 2) were due to environmental growth factors (e.g. light, temperature and water; Figures 1 and 2), which probably resulted in growth and appearance of leaves, and led to increased population density of tillers. This is in accordance with Matthew et al. (2000). On the other hand, the lowest rates of herb- 


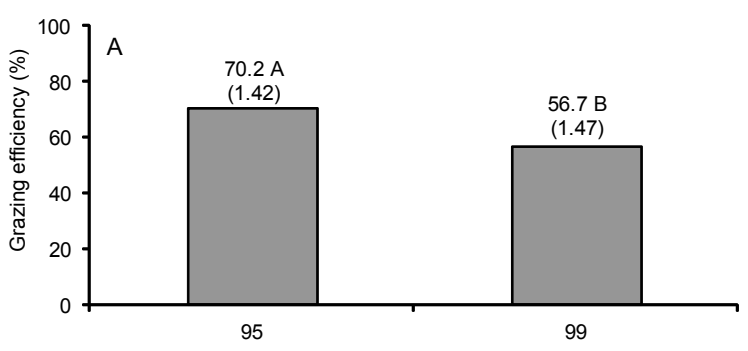

Light interception (\%)

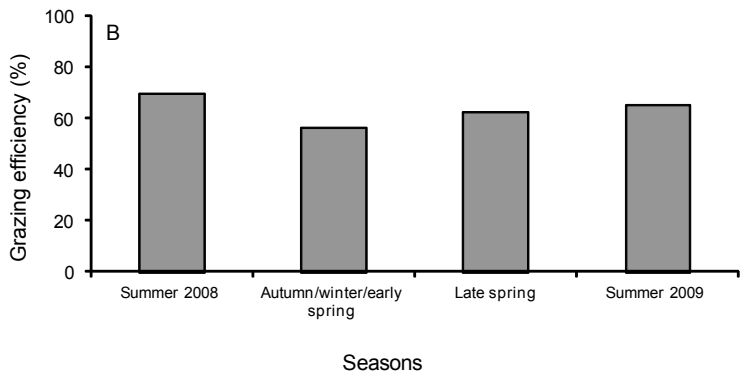

Summer 2008 = Jan 1 to Mar 31, 2008; autumn/winter/early spring = Apr 1 to Nov 15, 2008; late spring = Nov 16 to Dec 31, 2008; and summer 2009 $=$ Jan 1 to Mar 31, 2009. Means followed by the same uppercase letter are not different $(p>0.05)$. The values in parentheses correspond to the standard error of the mean.

Figure 4 - Grazing efficiency of mulato grass subjected to strategies of rotational stocking management characterized by the pregrazing conditions of 95 and $99 \%$ LI from Jan, 2008 to Mar, 2009.

age accumulation recorded during autumn/winter/early spring and late spring were possibly a reflection of soil water deficit that began in July and lasted until the end of Dec, 2008 (Figure 2).

The higher rates of herbage accumulation of swards managed at $20 \mathrm{~cm}$ relative to those managed at $15 \mathrm{~cm}$ post-grazing height (Table 3) may be explained by their larger residual leaf area index (Table 7) that possibly contributed to faster recovery of pasture growth after defoliation. In turn, this resulted in the pre-grazing targets being achieved sooner (Giacomini et al., 2009), with shorter grazing intervals, which resulted in larger number of grazing cycles during the experiment period (Table 1). During autumn/winter/early spring differences in herbage accumulation among treatments disappeared, certainly due to climatic conditions unfavorable for plant growth at that time of the year.

Overall, swards managed at $95 \%$ LI presented larger rates of leaf accumulation (late spring and summer 2009) and smaller rates of stem accumulation (all seasons) relative to those managed at $99 \%$ LI (Tables 4 and 5), indicating the importance of interrupting regrowth when swards were intercepting $95 \%$ of the in-
Table 7 - Residual leaf area index in the post-grazing of mulato grass subjected to strategies of rotational stocking management from Jan, 2008 to Mar, 2009.

\begin{tabular}{lcc}
\hline \multirow{2}{*}{ Season of the year } & \multicolumn{2}{c}{ Post-grazing height $(\mathrm{cm})$} \\
\cline { 2 - 3 } & 15 & 20 \\
\hline Summer 2008 & $1.4 \mathrm{Ba}$ & $2.4 \mathrm{Aa}$ \\
& $(0.07)$ & $(0.07)$ \\
Autumn/winter/early spring & $0.9 \mathrm{Bc}$ & $1.6 \mathrm{Ab}$ \\
& $(0.15)$ & $(0.15)$ \\
Late spring & $1.2 \mathrm{Bbc}$ & $1.7 \mathrm{Ab}$ \\
& $(0.09)$ & $(0.09)$ \\
Summer 2009 & $1.3 \mathrm{Bab}$ & $1.7 \mathrm{Ab}$ \\
& $(0.09)$ & $(0.09)$ \\
\hline
\end{tabular}

Summer 2008 = Jan 1 to Mar 31, 2008; autumn/winter/early spring = Apr 1 to Nov 15, 2008; late spring = Nov 16 to Dec 31, 2008; and summer $2009=$ Jan 1 to Mar 31, 2009. Means followed by the same uppercase letter in rows and lowercase letter in the columns are not different (Student t test; $p>0.05$ ). The values in parentheses correspond to the standard error of the mean.

cident light in order to control stem elongation and to favor accumulation of leaves. The largest stem accumulation rates recorded on swards subjected to the 99/15 treatment during autumn/winter/early spring (Table 5) were the consequence of the long intervals between grazing events associated with that grazing strategy (Table 1). From late spring onwards, grazing intervals became shorter; however, it was difficult to graze pastures down to the target $15 \mathrm{~cm}$ height (Table 1), which reinforces the concept that less-frequent grazing does not allow for adequate control of stem elongation and makes controlling grazing more difficult (Da Silva and Carvalho, 2005).

There was no difference in stem accumulation rate between post-grazing heights on swards managed at 95 \% LI, corroborating the results of Carnevalli et al. (2006) for mombaça grass (Panicum maximum cv. Mombaça). This result shows that frequency relative to severity of grazing is a key variable for effective control of stem elongation, which is the main morphological component that determines degeneration of sward structure (Da Silva et al., 2009) and limits the successful achievement of target stubble height, impairing herbage intake (Da Silva and Carvalho, 2005). This is essential to define the appropriate timing for interrupting regrowth (Da Silva et al., 2009) in order to be able to take advantage of the time lag between growth and senescence and stem elongation ensuring high proportion of leaves in sward herbage mass.

Only a fraction of the accumulated herbage was removed by the animals during grazing. Swards managed at $99 \%$ LI (Figure 3A) were characterized by larger herbage mass pre-grazing (Table 1) and larger herbage disappearance during grazing $(23 \%$ higher than on swards managed at $95 \% \mathrm{LI}$ ), especially during autumn/winter/ early spring and late spring (Figure 3B). On the other hand, swards managed at $99 \%$ LI were grazed a smaller number of times during the experiment (Table 1); with larger removal of herbage being recorded on swards 
grazed at $95 \% \mathrm{LI}$ and/or with the post-grazing height of $15 \mathrm{~cm}$. Such a result is consistent with the more favorable structural conditions of the sward canopy for grazing (Hirata et al., 2010) on swards managed at $95 \%$ LI, and corroborates the results of Carnevalli et al. (2006) and Difante et al. (2009), from analogous experiments, for mombaça and tanzania grasses, respectively.

However, only a portion of the herbage removed was actually consumed by the grazing animals. Part was lost to the soil pathway, characterizing inefficiency of the grazing process particularly during periods of limiting climatic conditions for pasture growth (Figure 4b). Thus, although the $99 \%$ LI treatments resulted in the largest amounts of herbage removal, they also resulted in greater losses (Table 6), especially during autumn/winter/early spring and late spring, when there was a smaller proportion of leaves and greater proportion of stems and dead material in the upper strata of sward canopy, a condition that could have negative implications to grazing (Fonseca et al., 2012). The total amount of losses to the soil pathway (grazing losses) per treatment was 2990, 3390,4820 and $5600 \mathrm{~kg} \mathrm{ha}^{-1}$ for treatments 95/20, 95/15, 99/20 and 99/15, respectively. In general, grazing losses per grazing cycle and season of the year were smaller on swards managed at $95 \%$ relative to those managed at $99 \%$ LI, particularly for the $20 \mathrm{~cm}$ post-grazing height, which resulted in smaller total losses at the end of the experiment despite the larger number of grazing cycles under those circumstances (Table 1).

On swards managed at $99 \%$ LI, it was usual to have some plant lodging pre- and post-grazing, a consequence of taller pre-grazing height/herbage mass and physical damage by grazing (caused by higher stocking rate), respectively. That certainly contributed to increased grazing losses and reduced grazing efficiency. Overall, grazing losses were $39 \%$ lower on swards managed at $95 \%$ LI, which led to higher grazing efficiency (Figure 4A). This suggests that high efficiency of grazing is associated with more frequent defoliation, since it generates sward structures that are characterized by lower pre-grazing heights and greater proportion of leaves relative to stems and dead material, favoring the harvest process by the grazing animals (Fonseca et al., 2012).

The higher pre-grazing herbage mass on swards managed at $99 \%$ LI (Table 1) was not the result of higher rates of herbage accumulation and was not associated with high grazing efficiency. Therefore, grazing at $95 \%$ LI down to a post-grazing height of $20 \mathrm{~cm}$ ensured high accumulation of leafy dry matter, resulting in faster recovery of swards and high efficiency of grazing, conditions that should also favor herbage intake and animal performance.

\section{Conclusions}

Under rotational stocking management, the targets of $95 \%$ LI pre-grazing (which is equivalent to a $30 \mathrm{~cm}$ height) and $20 \mathrm{~cm}$ post-grazing result in efficient grazing and high producing leafy pastures, highlighting the potential of Mulato grass pastures for animal production.

\section{Acknowledgements}

To CNPq for the sponsorship provided to the first author during the research and the support postgraduate program of UFV and ESALQ.

\section{References}

Barthram, G.T. 1985. Experimental techniques: the HFRO sward stick. p. 29-30. In: Alcock, M.M., ed. Hill farming research organization. Midlothian, VA, USA.

Carnevalli, R.A.; Da Silva, S.C.; Oliveira, A.A.; Uebele, M.C.; Bueno, F.O.; Hodgson, J.; Silva, G.V.; Moraes, J.P. 2006. Herbage production and grazing losses in Panicum maximum cv. Mombaça pastures under four grazing managements. Tropical Grasslands 40: 165-176.

Cunha, B.A.L.; Nascimento Júnior, D.; Silveira, M.C.T.; Montagner, D.B.; Euclides, V.P.B.; Da Silva, S.C.; Sbrissia, A.F.; Rodrigues, C.S.; Sousa, B.M.L.; Pena, K.S.; Vilela, H.H.; Silva, W.L. 2010. Effect of two post-grazing heights on morphogenic and structural characteristics of guinea grass under rotational grazing. Tropical Grassland 44: 253-259.

Da Silva, S.C.; Carvalho, P.C.F. 2005. Foraging behaviour and herbage intake in the favorable tropics/sub-tropics. p. 8195. In: McGilloway, D.A., ed. Grassland: a global resource. Wageningen Academic, Wageningen, The Netherlands.

Da Silva, S.C.; Bueno, A.A.O.; Carnevalli, R.A.; Uebele, M.C.; Bueno, F.O.; Hodgson, J.; Matthew, C.; Arnold, G.C.; Morais, J.P.G. 2009. Sward structural characteristics and herbage accumulation of Panicum maximum cv. Mombaça subjected to rotational stocking managements. Scientia Agricola 66: 8-19.

Difante, G.S; Nascimento Júnior, D.; Euclides, V.P.B.; Da Silva, S.C.; Barbosa, R.A.; Gonçalves, W.V. 2009. Sward structure and nutritive value of Tanzânia guineagrass subjected to rotational stocking managements. Brazilian Journal of Animal Science 38: 9-19.

Fonseca, L.; Mezzalira, J.C.; Bremm, C.; Filho, R.S.A.; Gonda, H.L.; Carvalho, P.C.F. 2012. Management targets for maximizing the short-term herbage intake rate of cattle grazing in Sorghum bicolor. Livestock Science 145: 205-211.

Giacomini, A.A.; Da Silva, S.C.; Sarmento, D.O.L.; Zeferino, C.V.; Trindade, J.K.; Souza Júnior, S.J.; Guarda, Del`Alamo, V.; Sbrissia, A.F.; Nascimento Júnior, D. 2009. Components of the leaf area index of Marandu palisadegrass swards subjected to strategies of intermittent stocking. Scientia Agricola 66: 721-732.

Gildersleeve, R.R.; Ocumpaugh, W.R.; Quesenberry, K.H.; Moore, J.E. 1987. Mob-grazing of morphologically different Aeschynomene species. Tropical Grasslands 21: 123-132.

Hirata, M.; Kunieda, E.; Tobisa, M. 2010. Short-term ingestive behaviour of cattle grazing tropical stoloniferous grasses with contrasting growth forms. Journal of Agriculture Science 148: 615-624.

LI-COR Biosciences. 1992. Plant Canopy Analyzer: LAI-2000; Operating Manual. LI-COR Biosciences, Lincoln, NE, USA. 
Matthew, C.; Assuero, S.G.; Black, C.K.; Sackville Hamilton, N.R. 2000. Tiller dynamics of grazed swards. p. 127-150. In: Lemaire, G.; Hodgson, J.; Moraes, A., eds. Grassland ecophysiology and grazing ecology. CABI, Wallingford, UK.

Pedreira, C.G.S.; Rosseto, F.A.A.; Da Silva, S.C.; Nussio, L.G.; Moreno, L.S.B.; Lima, M.L.P.; Leme, P.R. 2005. Forage yield and grazing efficiency on rotationally stocked pastures of Tanzania-1 guineagrass and Guaçu elephantgrass. Scientia Agricola 62: 433-439.

Van Raij, B.; Quaggio, J.A.; Silva, N.M. 1986. Extraction of phosphorus, potassium, calcium and magnesium from soils by an ion-exchange resin procedure. Communications in Soil Science and Plant Analysis 17: 547-566.

SAS Institute. SAS/STAT. 1996. User's Guide Statistics, 6.4. ed. SAS Institute, Cary, NC, USA.
Silveira, M.C.T.; Nascimento Júnior, D.; Cunha, B.A.L.; Difante, G.S.; Pena, K.S.; Da Silva, D.C.; Sbrissia, A.F. 2010. Effect of cutting interval and cutting height on morphogenesis and forage accumulation of guinea grass (Panicum maximum). Tropical Grassland 44: 103-108.

Thornthwaite, C.W.; Mather, R.J. 1955. The Water Balance. Drexel Institute of Technology, Centerton, NJ, USA.

United States Department of Agriculture [USDA]. 2012. Soil taxonomy: official soil series descriptions with series extent mapping capabilities. Available in: (http://soils.usda.gov/ technical/classification/osd/index.html) [Accessed Jan 25, 2012]

Wolfinger, R.D. 1993. Covariance structure selection in general mixed models. Communications in Statistics. Simulation and Computation 22: 1079-1106. 